1 This is the resubmitted (not the final printed) version of the manuscript. For

2 referencing please refer to the final article found at doi: 10.1016/j.quascirev.2013.07.015

\title{
Changes in current patterns in the Fram Strait at the
}

Gebhardt, A. C., Geissler, W. H., Matthiessen, J., and Jokat, W.

Alfred Wegener Institute Helmholtz Centre for Polar and Marine Research, Am Alten Hafen 26, 27568 Bremerhaven, Germany

\section{Abstract}

Seismic reflection profiles from the northwestern and central part of the Fram Strait show thick packages of drift type sediments mainly along the western Yermak Plateau flank, but also in the central, flat part of the Fram Strait. North of $80.5^{\circ} \mathrm{N}$, a large-scale field of sediment waves along the Yermak Plateau rise separates a western, lower from an eastern, upper drift body. These drift bodies were deposited by bottom currents, most likely the northbound Yermak Branch of the West Spitsbergen Current, but we cannot rule out that the western drift body may also have been influenced by southbound bottom currents. A stratigraphic boundary is clearly visible within the drift bodies and even more pronounced within the sediment waves, separating a lower package of waves migrating upslope at low angle $\left(\sim 5^{\circ}\right)$ from an upper package with significantly increased wave crest migration $\left(\sim 16.5^{\circ}\right)$. This stratigraphic boundary could be tracked along the seismic network and corresponds to the lithostratigraphic boundary between units IA and IB at ODP Leg 151, Site 911 that was dated to $2.7 \mathrm{Ma}$. The increase in wave-crest migration angle indicates a shift towards higher sedimentation rates at 2.7 Ma, which corresponds to the intensification of the Northern Hemisphere glaciation with a major expansion of the Greenland, Scandinavian, northern Barents Sea and North American ice sheets. The subaerially exposed Barents shelf and the expansion of the northern Barents Sea ice sheet (as well as Svalbard) are likely sources for enhanced erosion and enhanced fluvial input along the pathway of the West Spitsbergen 
Keywords: drift sediments; contourite; seismic reflection; Pliocene/Pleistocene; Fram Strait; Yermak Plateau; Arctic Ocean

\section{Introduction}

The Fram Strait is the only deep-water connection between the North Atlantic and the Arctic Ocean, and this narrow gateway channels both inflowing relatively warm and saline North Atlantic as well as outflowing cold and less saline water. Sediments along the eastern flank as well as in the central part of the Fram Strait are deposited mainly as contourites influenced by these currents (e.g., Eiken and Hinz, 1993; Howe et al., 2008). The Arctic Ocean and its surroundings are highly sensitive to climate change, and paleoclimate reconstructions in the Arctic realm have thus become a major research focus during the past decade (e.g., Jakobsson et al., 2010; Melles et al., 2012; Moran et al., 2006; Tripati et al., 2008). Paleoclimate change in the Arctic Ocean led to significant shifts in the current patterns (e.g., Haley et al., 2008; Knies et al., 2007), and since almost all Arctic water masses traverse the Fram Strait upon leaving the Arctic Ocean, it is highly likely that the changes in the current patterns would somehow be recorded in the Fram Strait sediments. Studying these sediments therefore helps to unravel the paleocurrent patterns in the Arctic Ocean and, thus, get a better insight into paleoclimate change that affected the Arctic realm.

In this study, we use a network of seismic reflection data (i) to map the sediment structures and geometries along the western flank of the Yermak Plateau and in the central part of the Fram Strait, and (ii) to identify changes in the sedimentation regime.

\section{Study area}

The area investigated in this current study comprises the Fram Strait and the adjacent western flank of the Yermak Plateau (Fig. 1). The Fram Strait is the only present deep-water connection between the North Atlantic and Arctic Ocean (Eiken and Hinz, 1993). It is located between the Svalbard Archipelago to the East and Greenland to the West between $78^{\circ} \mathrm{N}$ and $82^{\circ} \mathrm{N}$ and has a water depth of up to $3,000 \mathrm{~m}$ and a width of $200 \mathrm{~km}$. The bow-shaped Yermak Plateau is located north of the Svalbard archipelago with water depths of 700 to 800 $\mathrm{m}$ over large parts. The initial basement topography of the Yermak Plateau is rather rough with many deep troughs separating the basement heights (Geissler et al., 2011; Jokat et al., 2008). Cenozoic sediments of up to $4 \mathrm{~km}$ in thickness almost level this initial topography (Geissler et al., 2011) with exceptions of some basement heights such as the Sverdrup Bank that is still outcropping and not yet leveled completely. The sediments are generally welllayered and can mostly be interpreted as contourite deposits along the basement heights, 
the uppermost sediment layers indicated both by an overconsolidated diamicton and by mega-scale lineations of deep-keeled tabular icebergs and curvilinear plow marks of smaller, single icebergs (e.g., Dowdeswell et al., 2010; Gebhardt et al., 2011; Jakobsson et al., 2010; O'Regan et al., 2010; Vogt et al., 1994), but the western flank is characterized by welllayered drift-type sediments (e.g., Gebhardt et al., 2011; Geissler et al., 2011; Pulm, 2010).

\subsection{Evolution of the Fram Strait}

Even though seafloor spreading in the central Atlantic propagated northwards as early as in the late Cretaceous, the Arctic Ocean stayed isolated from the Atlantic Ocean probably until the separation of the Yermak Plateau from northeast Greenland some $35 \mathrm{Ma}$ ago (Ehlers and Jokat, 2013; Jokat et al., 2008; Moran et al., 2006). The onset of significant water exchange through the Fram Strait, however, is still under debate, but deep water exchange and, thus, ventilation of the Arctic Ocean, is likely to have started at $18.2 \mathrm{Ma}$, and a significant deepening of the Fram Strait is documented from 17.5 Myrs on (Jakobsson et al., 2007). The abyssal plain in the northern Fram Strait is underlain by young oceanic crust and the Lena Trough is still active as the current spreading center (Läderach et al., 2011).

\subsection{Oceanographic circulation through the Fram Strait}

The Fram Strait is channeling the flow of surface and deep waters between the Arctic and North Atlantic and allows the deep-water exchange between both polar hydrospheres (Fig 1). The currents flowing from the North Atlantic through the Norwegian Sea and towards the Arctic Ocean include the northward inflow of relatively warm and saline waters via the Norwegian Current and further as the West Spitsbergen Current along the western margin of Svalbard, and the southward outflow of cold and low saline waters along the Greenland shelf via the East Greenland Current (e.g., Bourke et al., 1988; Manley et al., 1992; Rudels et al., 2012) (Fig. 1). Within the Fram Strait, the West Spitsbergen Current splits into three components north of approximately $78^{\circ} \mathrm{N}$ (e.g., Quadfasel et al., 1987; Rudels et al., 2002). One component, the Spitsbergen Branch, turns eastward directly north of the Svalbard archipelago and flows along the shallow southern Yermak Plateau (Schauer et al., 2004). The second branch, the Return Atlantic Current, re-circulates towards south between $78^{\circ}$ and $80^{\circ} \mathrm{N}$ (Bourke et al., 1988), and the third branch, the Yermak Branch, transports water northwards along the western Yermak Plateau and enters the Arctic Ocean through the eastern Fram Strait, turning eastward at the northeastern tip of the plateau (Rudels et al., 2002) (Fig. 1). Within the Arctic Ocean, the warm water mass mixes with cold and fresh surface waters, and sea ice formation during Arctic winters enhances its salinity and, thus, its density. The water mass sinks, and flows as an intermediate water mass counterclockwise 
before being exported out of the Arctic Ocean via the Fram Strait along the east Greenland shelf as part of the East Greenland Current (Rudels et al., 2012).

\subsection{Age information}

112 All age information used for this study is derived from ODP Leg 151, Sites 909 and 911 (Fig.

113 2). The northern profiles (shown: AWI-20040040, 20040080, 20040150, 20040160; Figs. 3-6)

114 were dated following the stratigraphic correlations of Geissler and Jokat (2004) and Geissler 115 et al. (2011). These authors used information from correlations of seismic lines with ODP 116 Site 911, Leg 151. Site 911 was drilled in triplicate in summer 1993 (Myhre et al., 1995) with 117 RV Joides Resolution with $911 \mathrm{~A}$ at $80^{\circ} 28.466^{\prime} \mathrm{N}, 8^{\circ} 13.640^{\prime} \mathrm{E}$ being the deepest hole (terminal 118 depth $505.8 \mathrm{mbsf}$ ). Hole 911A was drilled in $901.6 \mathrm{~m}$ water depth at the eastern flank of the 119 Yermak Plateau (Fig. 1). The sediment record of Site 911 was described as homogeneous 120 silty clay and clayey silt, and was divided into lithological subunits IA and IB (Myhre et al., 121 1995) at 380.4 mbsf with the upper unit containing significantly more dropstones than the 122 lower one. The boundary between the two subunits was dated to 2.7 to $2.8 \mathrm{Ma}$ (Myhre et 123 al., 1995; Sato and Kameo, 1996) and corresponds to the base of seismostratigraphic unit 124 YP-3 (Eiken and Hinz, 1993; Geissler and Jokat, 2004).

125 Age information for the southwestern profiles (shown: AWI-97253; Fig. 6) derives from 126 correlations of seismic lines with ODP Site 909, Leg 151. Site 909 was drilled in triplicate in 127 summer 1993 with RV Joides Resolution with Hole $909 \mathrm{C}$ at $78^{\circ} 35.096^{\prime} \mathrm{N}, 3^{\circ} 4.222^{\prime} \mathrm{E}$ being 128 the deepest hole (terminal depth $1061.80 \mathrm{mbsf}$ ). Hole 909C was drilled in $2518 \mathrm{~m}$ water 129 depth immediately north of the Hovgård Ridge (Fig. 1) (Myhre et al., 1995). The sediment 130 record from Site 909 was subdivided into 3 lithological units I, II and III with the lowermost 131 subdivided into subunits IIIA and IIIB. Unit I spans the sediments between 0 and $248.8 \mathrm{mbsf}$ 132 and is dated to Quaternary to middle Pliocene (0 to $3.6 \mathrm{Ma}$; Winkler et al., 2002). It consists 133 of interbedded clay, silty clay and clayey mud and contains dropstones of $>1 \mathrm{~cm}$ in size 134 (Myhre et al., 1995). Unit II consists of more massive silty clay interbedded with thinner 135 layers of carbonate-rich clays without dropstones and contains the sediments between 248.8 136 and $518.3 \mathrm{mbsf}$ dated to Pliocene to Miocene age ( 3.6 to 6-7 Ma; Winkler et al., 2002) age. 137 Unit III contains the sediments below 518.3 mbsf (Myhre et al., 1995). Unit III can be further 138 subdivided into IIIA and IIIB at $923.4 \mathrm{mbsf}$ which corresponds to middle Miocene age 139 (Winkler et al., 2002). Subunit IIIA consists of silty and clayey sediments with meter-scale 140 intervals of thin bioturbated layers and laminations (Myhre et al., 1995). The sediments of 141 Subunit IIIB are folded and deformed and have a basal age of Early to Middle Miocene 142 (Winkler et al., 2002).

143 In order to correlate the southern to the northern profiles, we additionally used information 144 from Knies et al. (2009) who place the magnetostratigraphic Matuyama-Gauss boundary 
145 (2.581 Ma) at $186.40 \mathrm{mbsf}$ for Hole 909C. This boundary is very close to the YP-3/YP-2 146 boundary that was used in the northern profiles; at Hole 911A, these two boundaries are only 147 some $20 \mathrm{~m}$ apart (360 mbsf for the 2.581 Ma Matuyama-Gauss boundary vs. 380.4 mbsf for 148 the 2.7-2.8 Ma YP-3/YP-2 boundary).

\section{Data acquisition and processing}

151 Hydroacoustic and seismic data along the western flank of the Yermak Plateau were 152 collected mostly in parallel during RV Polarstern expedition ARK-XVIII/2 (Jokat, 2003) in 1532002 and ARK-XX/3 in 2004 (Stein, 2005), and profiles from the central part of the Fram 154 Strait were collected during RV Polarstern expedition ARK-XIII/3 (Krause, 1998) in 1997 and, 155 again, ARK-XVIII/2 in 2002. Navigation and positioning of all profiles used GPS in connection 156 with the ship's integrated inertial navigation system (MINS). Sediment echosounder data 157 were acquired with the hull-mounted PARASOUND system (Atlas Hydrographic, Germany; 158 P70) installed on RV Polarstern. Bathymetric data were collected with the RV Polarstern's 159 deep-water multibeam system DS-2 (Atlas Hydrographic, Germany) that operates on a 160 frequency of $15.5 \mathrm{kHz}$. A transmission beam aperture of $90^{\circ}$ was used during both 161 expeditions, resulting in a swath width of twice the mean water depth. Bathymetric data were 162 processed thoroughly comprising outlier rejection and editing of the navigation data using 163 CARIS-HIPS (Jokat, 2003; Stein, 2005). Sediment echosounder and bathymetric data were 164 used for comparison with the seismic reflection profiles for better understanding of the 165 sediment geometries and their according deposition and transport mechanisms. Seismic 166 data were processed using standard techniques (CMP sorting, NMO corrections, f-k filtering, 167 stacking, and bandpass filtering) (Geissler et al., 2011). Tracklines of all profiles used in this study are shown in Fig. 1.

\section{Description of seismic profiles}

171 Throughout our investigation area, the entire western flank of the Yermak Plateau is 172 characterized by large-scale sediment bodies. The lowest part of the sediment packages 173 (YP-1; Figs. 3 to 5) fills and levels the troughs of the rather rough acoustic basement (see 174 also Geissler et al., 2011). The upper two seismostratigraphic units (YP-2 and YP-3) exhibit 175 well-layered internal geometries that are quite similar over large N-S distances. The 176 geometries do not alter significantly from the lowermost to the uppermost part of each 177 individual unit, and layers are slightly thinner towards east and west and thicker in their 178 middle part where they bend (best visible in Fig. 4). The stacked layers build up a long, 179 elongated mound body relative to the lower boundary of the according seismostratigraphic 
180 units, and the crests of the layers migrate towards east. The line that connects the crests has 181 a slightly sigmoidal curve. Such sediments are commonly interpreted as contourite or drift 182 sediments (e.g., Faugères et al., 1999). In the case of the Yermak Plateau, these contourite 183 sediments occur in a scale of thousands of square kilometers. Also the central part of the 184 Yermak Plateau is leveled by thick packages of contourite sediments that fill the deep valleys and troughs of the rough acoustic basement topography (Geissler et al., 2011), but the uppermost part is eroded and incised by a grounded ice sheet and by keels of deep-draft mega-scale tabular icebergs (e.g. Dowdeswell et al., 2010; Gebhardt et al., 2011). Turbidite fans also build up large sediment bodies with well-layered internal geometries, but turbidites are often transported through turbidite channels before they are deposited. Such channels were not encountered at the western flank of the Yermak Plateau during the 2002 and 2004 expeditions. Furthermore, turbidite deposits would be expected at the deeper water depths, and not at the upper flank of the Yermak Plateau. The sediment facies encountered at the Yermak Plateau flank continues onto the top of the plateau. Also, turbidites would likely be thickest at their proximal and thin out towards their distal end, which is in contradiction with the geometries found in the sediment packages at the western Yermak Plateau flank. And furthermore, even though both turbiditic levées as well as contourite drifts tend to migrate downsteam, this would be in a downslope direction for the turbiditic depositions (Faugères et al., 1999), while at the Yermak Plateau, the crests move slightly upwards the slope. In conclusion, the sediments encountered here can definitely be interpreted as drift or contourite bodies rather than turbidite fans. It is however possible that further downstream of the current, e.g. at the Svalbard continental slope, turbidites bring sediment particles in suspension that are later deposited along the Yermak Plateau flanks.

203 North of $80.5^{\circ} \mathrm{N}$, two drift bodies were encountered along the western flank of the Yermak 204 Plateau. The two drift bodies are separated by a field of sediment waves. The western, lower 205 drift body, hereafter referred to as drift body A, is located at water depths of 2500 to $3500 \mathrm{~m}$, 206 the eastern, upper drift body, named drift body B, comprises the flank at water depths $<1630$ $207 \mathrm{~m}$. In the more central, deeper part of the Fram Strait, contourite sediments were observed in 208 several seismic profiles and can be interpreted as drift body A. In the following, a detailed 209 description of selected seismic profiles is given. All tracklines of these profiles are shown in 210 Fig. 1.

211 Profile AWI-20040040 was shot from the Lena Trough in the west to the Sverdrup Bank on 212 the central flat part of the Yermak Plateau (Fig. 1), with the western Yermak Plateau flank 213 between CDPs 3200 and 7200 (Fig. 3). The acoustic basement exhibits a rough topography 214 and is overlain by thick packages of rather well-layered sediments west of CDP 6200, while 215 the same packages are much thinner in the central Fram Strait area. At CDP 7200, a 216 topographic height of the basement was encountered, and sediment cover is thin or absent 
217 west of this topographic height. Seismostratigraphic units YP-3 and YP-2 exist both on the 218 Yermak Plateau and in the evolving Fram Strait area and extending towards the Lena 219 Trough, while the oldest unit YP-1 was likely only deposited on the Yermak Plateau. Some 220 faults are imaged at CDPs 4000, 5150, and 6600. A large slump scar marks the transition of 221 the rather smooth, flat upper part to a more inclined, steeper, lower part of the flank between 222 CDPs 5200 and 5700. Here, thick packages of YP-3 are missing. Both seismostratigraphic 223 units YP-3 and YP-2 can be interpreted as drift bodies deposited by contourite currents along 224 the western flank of the Yermak Plateau. Roughly between CDPs 5800 to 6100 , sediment 225 waves could be detected both in YP-3 and YP-2, separating the more western drift body A 226 from eastern drift body B. The area in which sediment waves could establish in older unit YP2272 is slightly more towards east than in younger unit YP-3.

228 Profile AWI-20040150 is much shorter than AWI-20040040 and only spans the western flank 229 of the Yermak Plateau. Seismostratigraphic units YP-3 and YP-2 are well-stratified and 230 exhibit the two drift bodies $A$ and $B$ separated by two packages of sediment waves of 231 different age between CDPs 1300 and 1800 (Fig. 4), very similar to what is observed in AWI232 20040040. In AWI-20040150, however, the lower sediment wave package is much less 233 pronounced than the upper one. YP-1 underlies YP-2 but its internal structures are less well 234 imaged.

235 Profile AWI-20040160 spans from the Lena Trough across the entire central Yermak 236 Plateau. The acoustic basement shows a rough topography overlain by thick packages of 237 YP-1 sediments (Fig. 5). These seem to extend into the Lena Trough, but are much thinner 238 there than below the Yermak Plateau flank. YP-1 does not show much internal details of 239 sedimentary structures, but the overlaying YP-2 and YP-3 again exhibit the two drift bodies A 240 and B separated by a distinct field of sediment waves between CDPs 1200 and 1800 (Fig. 6). 241 Between CDPs 600 and 800, a very local field of smaller-scale sediment waves is observed, 242 likely associated with a relative basement height at this position.

243 Profile AWI-97253 is located more towards south, in the central part of the Fram Strait, and 244 spans from the Greenland shelf in the west to the northernmost end of the Molloy Deep in 245 the east (Fig. 7). This profile exhibits a drift body in its western part between CDPs 2100 and 246 3800, and a channel-levée complex between CDPs 3800 and 5100 (Berger, 2009). 247 Lithostratigraphic units I, II and III defined at ODP Leg 151 Site 909 were correlated through 248 the seismic network and are indicated in this profile; unit I is subdivided into IA* and IB* with 249 IA* comprising the uppermost $2.581 \mathrm{Ma}$ according to a chronology by Knies et al. (2009) for 250 site 909. All units are characterized by well-layered sediments with drift-type characteristics; 251 stratigraphic boundaries are non-erosive and concordant. 
254 The western drift body $A$ is clearly separated from the eastern drift body $B$ north of $80.5^{\circ} \mathrm{N}$ 255 (Pulm, 2010). It is located along the lowest western Yermak Plateau rise and extends 256 towards the central Fram Strait north of $80.5^{\circ} \mathrm{N}$, and covers almost the complete central 257 Fram Strait south of $80.5^{\circ} \mathrm{N}$ (Fig. 8). Sediment layers are concave in YP-2 and fill the troughs 258 of the rough acoustic basement. At the YP-3/YP-2 boundary, they are almost leveled, and 259 they are flat to slightly concave slope-upwards in YP-3 (Figs. 3, 5). The layers do not show a 260 significant decrease in thickness from the central region towards its margins except very 261 local examples such as the trough fill shown in fig. 3 (CDPs 6700 to 7200). Within YP-2, all 262 sediment layers are thinner on the western and thicker on the eastern, slopeward side. Using 263 the theory that coriolis force-related deposition occurs to the right side of the flow direction on 264 the northern hemisphere (Faugères and Mulder, 2011; Faugères et al., 1999), this suggests 265 a formation by a northbound bottom current whose center is located where the thin layers are 266 encountered. This is most pronounced on profile AWI-20040040 (Fig. 3). Also profile AWI26720040160 (Fig. 5) suggests a northbound current that formed drift body A at least in its lower 268 part. For YP-3, however, the flow direction of the associated current cannot reliably be determined from the sediments; a modeling study by Schlichtholz and Houssais (1999) suggests southbound deep water currents at depths larger than $1500 \mathrm{~m}$. This would imply that drift body A was likely formed by a northbound current in unit YP-2 and by a southbound current in unit YP-3. Smaller-scale sediment waves found between CDPs 600 to 800 in AWI20040160 overlay a relative basement height that is not yet completely leveled and may act as a local obstacle in the otherwise smooth present topography, and as such induce the formation of these smaller-scale sediment waves.

276 A second, significantly larger field of sediment waves is observed in all profiles along the western slope of the Yermak Plateau, separating drift bodies A and B (Figs. 3-6, 8). The sediment-wave field is formed in water depths of $\sim 2500$ to $1600 \mathrm{~m}$. Sediment waves are often associated with drift bodies and occur where slopes change their angle significantly, as is the case for the observed area.

281 Crests of sediment waves normally are oriented perpendicular to the current by which they 282 are formed. Sediment waves consisting of fine-grained material, however, tend to be oriented 283 more obliquely to the current (Howe et al., 1998), and sediment waves on slopes (slope angle $>2^{\circ}$ at the wave field location; Pulm, 2010) typically have low angles of $\sim 10^{\circ}$ to $50^{\circ}$ to the flow (Wynn and Masson, 2008). Fig. 9a shows that the crests of the sediment waves move upslope, which suggests that they were generated by a current with a slight upslope component. It is however unclear if this is the current associated with drift body A or B, respectively. Figure $9 \mathrm{~b}$ shows the crests of some of the sediment waves. They are oriented roughly in N-S direction, but with a slight angle towards NNW-SSE in the more southern and 
towards NNE-SSW in the more northern part. One sediment wave obviously has a curvilinear

291 crest shape, but the swath of the bathymetry data is too small to resolve the crest geometry

292 reliably. The general alignment of the sediment waves points at a north- or southbound

293 bottom current but does not allow specifying more precisely. The angle between the more

294 southern and the more northern crests points at a slight rotation of the bottom current in this

295 area.

296 The sediment waves are generally well-layered with wavelengths of 1500 to $2000 \mathrm{~m}$ and 297 amplitudes in the range of 3 to $10 \mathrm{~m}$ (Fig. 9a). The entire package of sediment waves can be 298 subdivided at the boundary between seismostratigraphic units YP-2 and YP-3 where a 299 significant change in the outer shape of the waves is observed. Here, the angle in which the 300 wave crests migrate upslope changes from $\sim 5^{\circ}$ in the older YP-2 waves to much steeper $301 \sim 16.5^{\circ}$ in the younger YP-3 waves (Pulm, 2010). The YP-2 sediment waves show 302 sedimentation only on the upslope side of the wave, while the downslope side is 303 characterized by non-deposition or even erosion (Fig. 9a). The younger sediment waves of 304 YP-3, in contrast, show net deposition on both the upslope and the downslope side (Pulm, 305 2010). This points at a significant change in bottom current speed and/or sediment supply 306 from lower sedimentation rates and stronger currents in older YP-2 to enhanced 307 sedimentation rates along with lower current speeds in the younger YP-3 (Wynn and 308 Masson, 2008).

309 Eastern drift body $B$ is located on the continental slope at water depths $<1630 \mathrm{~m}$ and is 310 visible in the seismic data throughout the entire western Yermak Plateau slope, and it 311 extends onto the central part of the Yermak Plateau (Gebhardt et al., 2011; Geissler et al., 312 2011) (Fig. 8). The crest of drift body $B$ is gradually migrating upslope within YP-3 as well as 313 within YP2, but at the boundary between the two units, shape and location of the crest 314 change significantly and abruptly from a more western position in YP-2 to a more eastern 315 position in YP-3. The stratigraphic boundary between YP-3 and YP-2 is non-erosive and 316 concordant along the flanks throughout the entire investigation area. Using the classification 317 of Faugères and Stow (2008), drift body B can be interpreted as a mounded drift, likely of 318 "plastered drift" type accumulated by a fairly constant, low-velocity current. This can be 319 stated for both the younger YP-3 and the older YP-2 part of the drift body; internal sediment 320 structures within YP-1 are not imaged clearly enough to interpret its accumulation 321 mechanism reliably.

322 Drift body B lies in the flow path of the Yermak Branch of the West Spitsbergen Current. This 323 northbound current transports heat from the North Atlantic into the Arctic Ocean. 324 Furthermore, this current is characterized by a high suspension load in the bottom layer, 325 which is also mirrored in a rich benthic fauna along its track (Rutgers van der Loeff et al., 326 2002). It is quite likely that this current deposited large parts of the thick sediment packages 
327 that fill and almost level the rough basement topography of the Yermak Plateau as described

328 for example in Geissler et al. (2011). The change in sedimentation that is visible at the YP-

329 2/YP-3 boundary does not affect the general shape of the drift body but rather its relative

330 position on the western Yermak Plateau flank, i.e. the drift body is moved upslope. This

331 suggests that not only the upper part of this drift body, but also the older YP-2 part was likely

332 deposited associated with a northbound bottom current. Only locally and associated with

333 topographic heights, the bottom currents on the central Yermak Plateau may be deflected

334 and flow in opposite direction (Gebhardt et al., 2011).

335 In spring 2002, an oceanographic profile was measured along approximately $81.33^{\circ} \mathrm{N}$ on the

336 Swedish icebreaker IB Oden (Rudels et al., 2005). The easternmost station of this profile

337 was located at $\sim 82^{\circ} \mathrm{N}$ just west of the Yermak Plateau, somewhat north of profile AWI-

338 20040040. The Yermak Branch was only identified east of the zero meridian in this

339 oceanographic profile, while southbound flow was measured west of it. This would mean that

340 drift body A could be influenced also by a southbound current in its westernmost part;

341 topography however is complicated in this area and deflection of both the northbound and

342 the southbound currents are highly likely. Drift body A, in our opinion, does not show

343 significant signs of a southbound current in nearby profile AWI-20040040, but we can also

344 not exclude that at least temporarily a southbound current may influence this drift body.

345 Further to the south, in profile AWI-97253, a channel-levée complex is visible (Fig. 7). While

346 the northeastern flank of the Fram Strait, i.e. the Yermak Plateau flank, is mainly influenced

347 by lateral sediment transport processes (Howe et al., 2008; Pulm, 2010), downslope

348 processes are common on the entire Greenland side (Berger and Jokat, 2008, 2009; Ó

349 Cofaigh et al., 2004). The study by Ó Cofaigh et al. (2004) revealed the northeast Greenland

350 continental margin as an area with an extensive system of submarine channels with

351 turbidites formed predominantly during full glacial and deglacial conditions. A study by Eiken

352 and Hinz (1993) on several seismic profiles from along the entire western Spitsbergen slope

353 showed the occurrence of mixed turbidite/contourite deposits also on the eastern Fram Strait

354 flank south of $\sim 80^{\circ} \mathrm{N}$. The drift body that was described west of the channel-levée complex

355 can therefore be interpreted in this context as deriving from a mixed turbidite/contourite

356 system. The influence of downslope sediment processes from the Greenland shelf is also

357 obvious from an erosive, large-scale mass movement deposit, likely a debris flow, that is

358 intercalated in the well-layered sediments of the drift body with an age somewhat younger

359 than the $I A^{*} / I B^{*}$ boundary, i.e. younger than 2.6 Ma. The channel-levée complex identified on

360 profile AWI-97253 likely is not a typical turbidite channel as it has overbank deposits on both

361 sides, but formed due to the highly variable topography around the Molloy Deep in

362 combination with the local bottom currents. Within the channel-levée complex, both a

363 northbound current in the eastern and a southbound current in the western part can be 
364 derived from the large step-like levees confining the entire channel (Fig. 7), following the 365 general theory that contourite behaviour and coriolis force-related deposition is to the right of 366 the flow direction (e.g., Faugères and Mulder, 2011). During the past two decades, several 367 oceanographic profiles were measured along $\sim 79^{\circ} \mathrm{N}$, i.e. south of profile AWI-97253 (e.g. 368 Beszczynska-Möller et al., 2012; Schauer et al., 2004). These profiles show that the Atlantic 369 Return Current is turning exactly in this area around the Molloy and Hayes Deeps, which is in good agreement with our data.

371 The large-scale drift bodies deposited in the entire eastern Fram Strait are associated with 372 the northbound West Spitsbergen Current in the southern part, and from the Yermak Branch 373 and the Spitsbergen Branch in which the West Spitsbergen Current is split north of the 374 Svalbard Archipelago. Since not only the southernmost Yermak Plateau and the western 375 flank are characterized by large drift bodies, but in fact the entire central part of the rough 376 basement topography of the plateau is filled in and leveled by thick packages of such sediments, it is likely that the bottom current pattern is much more complicated in this area, with a bottom current flowing like a large sheet over the entire range in between the Yermak and the Spitsbergen Branch. This is confirmed by a modeling study by Schlichtholz and Houssais (1999). This large current system is locally disturbed by obstacles such as relative basement heights (e.g. around the Sverdrup Bank; Gebhardt et al., 2011), but the general flow trend is SW-NE. Along the western Yermak Plateau flank, the Yermak Branch flows northwards and turns towards northeast only at about $81.5^{\circ} \mathrm{N}$, following the topography of the plateau. At around $82^{\circ} \mathrm{N}$, the plateau exhibits a roughly SE-NW trending bedrock sill that functions as a large obstacle and likely reduces the current speed. Current velocities decrease significantly along the pathway of the northbound currents in the Fram Strait: Fahrbach et al. (2001) report velocities of up to $24 \mathrm{~cm} \mathrm{~s}^{-1}$ in the near bottom layer of the core of the West Spitsbergen Current at $79^{\circ} \mathrm{N}$, and (Schlichtholz and Houssais, 1999) modeled velocities as low as 1 to $3 \mathrm{~cm} \mathrm{~s}^{-1}$ for the Yermak Branch (named Yermak Slope Current in their study). A gradient within the current speeds with a decreasing trend towards north could also be responsible for a discrepancy in the sediment patterns encountered between the southern and northern part of the Fram Strait. Signs of erosion were found in the southern part, at the Vestnesa drift (Howe et al., 2008), i.e. where current velocities are high. Towards north, the drift bodies show parallel layering, and further north divergent layering becomes more and more dominant (Pulm, 2010). Water masses carry a high suspension load along the northwestern Svalbard continental slope, and this sediment load is deposited where current velocities are lower, resulting in parallel layering within the drift bodies. Towards north, divergent layering witnesses the decrease in sedimentation (Pulm, 2010).

399 The most striking feature in the entire sediment succession along the western Yermak 400 Plateau flank is the distinct change in sediment geometries at the YP-3/YP-2 boundary, i.e. 
at $2.7 \mathrm{Ma}$. This change is best visible in the sediment waves and less distinct in the drift bodies (Figs. 3-5, 9). This change is synchronous with the onset of the Northern Hemisphere glaciation that is commonly assumed for $\sim 2.7 \mathrm{Ma}$ (e.g., Haug et al., 2005). Prior to $2.7 \mathrm{Ma}$, the Arctic realm was mostly ice-free, and temperatures were significantly higher than today (Brigham-Grette et al., 2013; Ravelo, 2010). A gradual or stepwise cooling since approximately 3.6 Ma was described by many authors (e.g.,Brigham-Grette et al., 2013; Flesche Kleiven et al., 2002; Mudelsee and Raymo, 2005). But even though the initiation of large-scale glaciation of the northern hemisphere started already approximately 1 million years earlier, ice-sheet development in Greenland, Scandinavia and North America was initiated approximately synchronously at 2.72-2.73 Ma (Flesche Kleiven et al., 2002)., and also in northwestern Svalbard, glaciers reached the shelf break at around 2.6 to $2.8 \mathrm{Ma}$ (Sarkar et al., 2011). It seems that also the current system in the Fram Strait has changed significantly at the same time. This change apparently did not happen gradually, and it is quite likely that it is closely related to the development of the ice sheets in the Fram Strait hinterland mainly in the Barents Sea and Svalbard area. In profile AWI-97253 from the southern Fram Strait, the YP-3/YP-2 boundary could not be spotted (seismostratigraphic correlation with the Yermak Plateau ODP sites 910-912 impossible), but instead the 2.6 Ma timeline defined at ODP site 909 (Knies et al., 2009) is indicated (IA*/IB* boundary, Fig. 6). Here, this timeline does not coincide with a change in the sediment pattern, so the change did possibly only affect the northern Fram Strait, not the southwestern part. The change in sediment wave geometries and migration angle indicate a significant increase of sedimentation rates at $\sim 2.7 \mathrm{Ma}$. Such an increase could be reached by an enhanced suspension load of the water masses that are depositing drift body $B$ and the sediment waves. The respective currents flow along the Norwegian and the Svalbard continental margin and incorporate fluvial and fluvioglacial input, and the proximity of glaciers at the northwestern Svalbard shelf break (Sarkar et al., 2011) could have served as a source for suspended material. Enhanced erosion on both Scandinavia and the Svalbard Archipelago would enrich the suspension load of the West Spitsbergen Current. Butt et al. (2002, and references therein) showed in a modeling study comprising the past $2.3 \mathrm{Ma}$ that the Barents shelf was subaerially exposed at $2.3 \mathrm{Ma}$, and only at around $\sim 1.0 \mathrm{Ma}$ major parts of the shelf became marine. Laberg et al. (2010) showed that in the Barents Sea region, glaciers terminated on land in the Barents Sea region between 2.7 and $1.5 \mathrm{Ma}$, and sediment was transported to the paleo-shoreline in a glaciofluvial manner. After $1.5 \mathrm{Ma}$, glaciers reached the shelf break and sediment transport occurred subglacially (Laberg et al., 2010), and Knies et al. (2009) show a large-scale intensification of glaciation in the Barents Sea around 1 Ma. This region, therefore, likely acted as a major source for additional suspension load of the West Spitsbergen Current. Enhanced suspension load of the currents could also be 
achieved by higher velocities along the Norwegian and Svalbard margin, resulting in higher energies and, thus, higher erosion rates. The currents slow down towards north, and sedimentation of the suspended material can take place. An exposed Barents shelf would not only lead to higher subaerial erosion rates, but also hinder the inflow of Atlantic waters north of Scandinavia through the Barents Sea and the St Anna Trough into the Arctic Ocean, as is currently the case (Butt et al., 2002). This would, in turn, channel the inflow of Atlantic water almost entirely through the Fram Strait, probably with higher flow velocities. It is however striking that the major change in ice sheet expansion in the Barents Sea at around 1 $\mathrm{Ma}$ is not reflected in the drift bodies along the western flank of the Yermak Plateau, while the onset of the northern hemisphere glaciation at around 2.7 Ma apparently led to a major change in suspension load and likely also changes in the current patterns.

\section{Conclusion}

The compilation of seismic profiles from the Fram Strait revealed large-scale drift sediments along the western Yermak Plateau flank. North of $80.5^{\circ} \mathrm{N}$, a large field of sediment waves were encountered that separate a western, deeper from an eastern, shallower drift body. A seismostratigraphic boundary is clearly visible within the drift bodies and even more distinct within the sediment waves. Correlations with ODP Leg 151 Hole 911 reveal that this coincides with the boundary between lithostratigraphic units $\mathrm{IA}$ and $\mathrm{IB}$, corresponding to seismic units YP-3 and YP-2. This boundary was dated to 2.7 Ma (Hull et al., 1996), which corresponds to the major ice-sheet expansion of the Greenland, Scandinavian and North American ice sheets. Sediment waves exhibit a shift to much higher migration angles of the wave crests at $2.7 \mathrm{Ma}$. This implies significantly increased sedimentation rates, pointing at a much higher suspension load of the West Spitsbergen Current and of the Yermak Branch. The Barents shelf which was subaerially exposed until 1 Ma (Butt et al., 2002), which makes it a likely source area, later on replaced by Svalbard.

\section{Acknowledgements}

466 We thank all expedition and crewmembers of RV Polarstern ARK-XIII/3, ARK-XVIII/2 and 467 ARK-XX/3 for their excellent work onboard. Special thanks go to the watch keepers of the 468 bathymetry, seismic and sediment echosounder systems. We thank Pia Pulm who carried out extensive work on the profiles on the western flank of the Yermak Plateau for her diploma thesis, and Dr. Daniela Berger who worked on the profiles from the central Fram Strait for her $\mathrm{PhD}$ thesis. Maps were generated using the Generic Mapping Tools software (Wessel and Smith, 1991) and the IBCAO v.3 chart (Jakobsson et al., 2012). 
Berger, D., 2009. Sedimentation history along the East Greenland margin, Alfred Wegener Institute Bremerhaven. University of Bremen, PhD thesis, Bremen, p. 134.

Berger, D., Jokat, W., 2008. A seismic study along the East Greenland margin from $72^{\circ} \mathrm{N}$ to $77^{\circ} \mathrm{N}$. Geophysical Journal International $174,733-748$.

Berger, D., Jokat, W., 2009. Sediment deposition in the northern basins of the North Atlantic and characteristic variations in shelf sedimentation along the East Greenland margin. Marine and Petroleum Geology 26, 1321-1337.

Beszczynska-Möller, A., Fahrbach, E., Schauer, U., Hansen, E., 2012. Variability in Atlantic water temperature and transport at the entrance to the Arctic Ocean, 1997-2010. ICES Journal of Marine Sciences 69, 852-863.

Bourke, R.H., Weigel, A.M., Paquette, R.G., 1988. The Westward Turning Branch of the West Spitsbergen Current. Journal of Geophysical Research 93, 14065-14077.

Brigham-Grette, J., Melles, M., Minyuk, P.S., Andreev, A.A., Tarasov, P., DeConto, R.M., König, S., Nowaczyk, N.R., Wennrich, V., Rosén, P., Haltia-Hovi, E., Cook, T.L., Gebhardt, A.C., Meyer-Jacob, C., Snyder, J., Herzschuh, U., 2013. Pliocene warmth, extreme polar amplification, and stepped Pleistocene cooling recorded in NE Russia. Science.

Butt, F.A., Drange, H., Elverhøi., A., Otterå, O.H., Solheim, A., 2002. Modelling Late Cenozoic isostatic elevation changes in the Barents Sea and their implications for oceanic and climatic regimes: preliminary results. Quaternary Science Reviews 21, 1643-1660.

Dowdeswell, J.A., Jakobsson, M., Hogan, K.A., O'Regan, M., Backman, J., Evans, J., Hell, B., Löwemark, L., Marcussen, C., Noormets, R., Ó Cofaigh, C., Sellén, E., Sölvsten, M., 2010. High-resolution geophysical observations of the Yermak Plateau and northern Svalbard margin: implications for ice-sheet grounding and deep-keeled icebergs. Quaternary Science Reviews 29, 3518-3531.

Ehlers, B.-M., Jokat, W., 2013. Paleo-bathymetry of the northern North Atlantic and consequences for the opening of the Fram Strait. Marine Geophysical Research, 1-19. Eiken, O., Hinz, K., 1993. Contourites in the Fram Strait. Sedimentary Geology 82, 15-32. Fahrbach, E., Meincke, J., Østerhus, S., Rohardt, G., Schauer, U., Tverberg, V., Verduin, J., 2001. Direct measurements of volume transports through Fram Strait. Polar Research 20, 217-224.

Faugères, J.-C., Mulder, T., 2011. Contour Currents and Contourite Drifts, In: Huneke, H., Mulder, T. (Eds.), Developments in Sedimentology. Elsevier, pp. 149-214.

Faugères, J.-C., Stow, D.A.V., 2008. Contourite drifts: Nature, Evolution and Controls In: Rebesco, M., Camerlenghi, A. (Eds.), Contourites. Developments in Sedimentology, pp. 259-288.

Faugères, J.-C., Stow, D.A.V., Imbert, P., Viana, A., 1999. Seismic features diagnostic of contourite drifts. Marine Geology 162, 1-38.

Fieg, K., Gerdes, R., Fahrbach, E., Beszczynska-Möller, A., Schauer, U., 2010. Simulation of oceanic volume transports through Fram Strait 1995-2005. Ocean Dynamics 60, 491502.

Flesche Kleiven, H., Jansen, E., Fronval, T., Smith, T.M., 2002. Intensification of Northern Hemisphere glaciations in the circum Atlantic region (3.5-2.4 Ma) - ice-rafted detritus evidence. Palaeogeography, Palaeoclimatology, Palaeoecology 184, 213-223. 
Gebhardt, A.C., Jokat, W., Niessen, F., Matthiessen, J., Geissler, W.H., Schenke, H.-W., 2011. Ice sheet grounding and iceberg plow marks on the northern and central Yermak Plateau revealed by geophysical data. Quaternary Science Reviews 30, 1726-1738. margin. Geophysical Journal International 158, 50-66.

Geissler, W.H., Jokat, W., Brekke, H., 2011. The Yermak Plateau in the Arctic Ocean in the light of reflection seismic data - implication for its tectonic and sedimentary evolution. Geophysical Journal International 187, 1334-1362.

Gradstein, F.M., Ogg, J.G., Hilgen, F.J., 2012. On the geologic time scale. Newsletter on Stratigraphy 45, 171-188.

Haley, B.A., Frank, M., Spielhagen, R.F., Eisenhauer, A., 2008. Influence of brine formation on Arctic Ocean circulation over the past 15 million years. Nature Geoscience 1.

Haug, G.H., Ganopolski, A., Sigman, D.M., Rosell-Mele, A., Swann, G.E.A., Tiedemann, R., Jaccard, S.L., Bollmann, J., Maslin, M.A., Leng, M.J., Eglinton, G., 2005. North Pacific seasonality and the glaciation of North America 2.7 million years ago. Nature 433, 821825.

Howe, J.A., Livermore, R.A., Maldonaldo, A., 1998. Mudwave activity and currentcontrolled sedimentation in Powell Basin, northern Weddell Sea, Antarctica. Marine Geology 149, 229-241.

Howe, J.A., Shimmield, T.M., Harland, R., 2008. Late Quaternary contourites and glaciomarine sedimentation in the Fram Strait. Sedimentology 55, 179-200.

Hull, D., Ostermann, L.E., Thiede, J., 1996. Biostratigraphic synthesis of Leg 151, North Atlantic-Arctic Gateway, In: Thiede, J., Myhre, A.M., Firth, J.V., Johannessen, O.M., Ruddiman, W.F. (Eds.), Proceedings of the Ocean Drilling Program, Scientific Results, pp. 627-644.

Jakobsson, M., Backman, J., Rudels, B., Nycander, J., Frank, M., Mayer, L.A., Jokat, W., Sangiorgi, F., O'Regan, M., Brinkhuis, H., King, J.W., Moran, K., 2007. The early Miocene onset of a ventilated circulation regime in the Arctic Ocean. Nature 447, 986-990.

Jakobsson, M., Macnab, R., Mayer, L.A., Anderson, R., Edwards, M.H., Hatzky, J., Schenke, H.W., Johnson, P.D., 2008. An improved bathymetric potrayal of the Arctic Ocean: Implication for an ocean modeling and geological, geophysical and oceanographic analyses. Geophysical Research Letters 35, L07602.

Jakobsson, M., Mayer, L.A., Coakley, B., Dowdeswell, J.A., Forbes, S., Fridman, B., Hodnesdal, H., Noormets, R., Pedersen, R., Rebesco, M., Schenke, H.-W., Zarayskaya A, Y., Accettella, D., Armstrong, A., Anderson, R.M., Bienhoff, P., Camerlenghi, A., Church, I., Edwards, M., Gardner, J.V., Hall, J.K., Hell, B., Hestvik, O.B., Kristoffersen, Y., Marcussen, C., Mohammad, R., Mosher, D., Nghiem, S.V., Pedrosa, M.T., Travaglini, P.G., Weatherall, P., 2012.

The International Bathymetric Chart of the Arctic Ocean (IBCAO) Version 3.0. Geophysical Research Letters.

Jakobsson, M., Nilsson, J., O'Regan, M., Backman, J., Löwemark, L., Dowdeswell, J.A., Mayer, L., Polyak, L., Colleoni, F., Anderson, L.G., Björk, G., Darby, D., Eriksson, B., Hanslik, D., Hell, B., Marcussen, C., Sellén, E., Wallin, Å., 2010. An Arctic Ocean ice shelf during MIS 6 constrained by new geophysical and geological data. Quaternary Science Reviews 29, 3505-3517

Jokat, W., 2003. The Expedition ARKTIS XVIII/2 of RV "Polarstern" in 2002 Contributions of the Participants.

Jokat, W., Geissler, W.H., Voss, M., 2008. Basement structure of the north-western Yermak Plateau. Geophysical Research Letters 35, L05309. 
Knies, J., Matthiessen, J., Mackensen, A., Stein, R., Vogt, C., Frederichs, T., Nam, S.-I., 2007. Effects of Arctic freshwater forcing on thermohaline circulation during the Pleistocene. Geology 35, 1075-1078.

Knies, J., Matthiessen, J., Vogt, C., Laberg, J.S., Hjelstuen, B.O., Smelror, M., Larsen, E., Andreassen, K., Eidvin, T., Vorren, T.O., 2009. The Plio-Pleistocene glaciation of the Barents Sea-Svalbard region: a new model based on revised chronostratigraphy. Quaternary Science Reviews 28, 812-829.

Krause, G., 1998. The Expedition ARKTIS-XIII/3 of RV "Polarstern" in 1997. Laberg, J.S., Andreassen, K., Knies, J., Vorren, T.O., Winsborrow, M., 2010. Late PliocenePleistocene development of the Barents Sea Ice Sheet. Geology 38, 107-110.

Läderach, C., Schlindwein, V., Schenke, H.-W., Jokat, W., 2011. Seismicity and active tectonic processes in the ultra-slow spreading Lena Trough, Arctic Ocean. Geophysical Journal International 184, 1354-1370. Manley, T.O., Bourke, R.H., Hunkins, K.L., 1992. Near-surface circulation over the Yermak plateau in northern Fram Strait. Journal of Marine Systems 3, 107-125. Melles, M., Brigham-Grette, J., Minyuk, P.S., Nowaczyk, N.R., Wennrich, V., DeConto, R.M., Anderson, P.M., Andreev, A.A., Coletti, A., Cook, T.L., Haltia-Hovi, E., Kukkonen, M., Lozhkin, A.V., Rosén, P., Tarasov, P., Vogel, H., Wagner, B., 2012. 2.8 million years of Arctic climate change from Lake El'gygytgyn, NE Russia. Science 337, 315-320. Moran, K., Backman, J., Brinkhuis, H., Clemens, S.C., Cronin, T., Dickens, G.R., Eynaud, F., Gattacceca, J., Jakobsson, M., Jordan, R.W., Kaminski, M., King, J.W., Koc, N., Krylov, A., Martinez, N., Matthiessen, J., McInroy, D., Moore, T.C., Onodera, J., O'Regan, M., Pälike, H., Rea, B., Rio, D., Sakamoto, T., Smith, D.C., Stein, R., St John, K., Suto, I., Suzuki, N., Takahashi, K., Watanabe, M., Yamamoto, M., Farrell, J., Frank, M., Kubik, P., Jokat, W., Kristoffersen, Y., 2006. The Cenozoic palaeoenvironment of the Arctic Ocean. Nature 441, 601-605.

Mudelsee, M., Raymo, M.E., 2005. Slow dynamics of the Northern Hemisphere glaciation. Paleoceanography 20, PA4022.

Myhre, A.M., Thiede, J., Firth, J.V., Ahagon, N., Black, K.S., Bloemendal, J., Brass, G.W., Bristow, J.F., Chow, N., Cremer, M., Davis, L., Flower, B., Fronval, T., Hood, J., Hull, D., Koç, N., Larsen, B., Lyle, M., McManus, J., O'Connel, S., Ostermann, L.E., Rack, F.R., Sato, T., Scherer, R., Spiegler, D., Stein, R., Tadross, M., Wells, S., Williamson, D., Witte, B., WolfWelling, T., 1995. Proceedings of the Ocean Drilling Program, Initial Reports, Leg 151. College Station, Texas.

O'Regan, M., Jakobsson, M., Kirchner, N., 2010. Glacial geological implications of overconsolidated sediments on the Lomonosov Ridge and Yermak Plateau. Quaternary Science Reviews 29, 3532-3544.

Ó Cofaigh, C., Dowdeswell, J.A., Evans, J., Kenyon, N.H., Taylor, J., Mienert, J., Wilken, M., 2004. Timing and significance of glacially influenced mass-wasting in the submarine channels of the Greenland Basin. Marine Geology 207, 39-54.

Pulm, P., 2010. Sedimentation processes in the northern Fram Strait since early Miocene, Fakultät für Mathematik, Informatik und Naturwissenschaften. University of Hamburg, Diploma thesis, Hamburg, p. 218.

Quadfasel, D., Gascard, J.-C., Koltermann, K.-P., 1987. Large-scale oceanography in Fram Strait during the 1984 Marginal Ice Zone Experiment. Journal of Geophysical Research, 6719-6728. 
along the East Greenland Current: results from the Arctic Ocean-02 Oden expedition. Journal of Marine Systems 55, 1-30. Rudels, B., Fahrbach, E., Meincke, J., Budeus, G., Eriksson, P., 2002. The East Greenland Current and its contribution to the Denmark Strait overflow. ICES Journal of Marine Science: Journal du Conseil 59, 1133-1154. Quadfasel, D., Valdimarsson, H., 2012. The East Greenland Current and its impacts on the Nordic Seas: observed trends in the past decade. ICES Journal of Marine Sciences 69, 111. Rutgers van der Loeff, M.M., Meyer, R., Rudels, B., Rachor, E., 2002. Resuspension and particle transport in the benthic nepheloid layer in and near Fram Strait in relation to faunal abundances and ${ }^{234}$ Th depletion. Deep-Sea Research I 49, 1941-1958.

Sarkar, S., Berndt, C., Chabert, A., Masson, D.G., Minshull, T.A., Westbrook, G.K., 2011. Switching of a paleo-ice stream in northwest Svalbard. Quaternary Science Reviews 30, 1710-1725.

Sato, T., Kameo, K., 1996. Pliocene to Quaternary calcareous nannofossil biostratigraphy of the Arctic Ocean, with reference to late Pliocene glaciation, In: Thiede, J., Myhre, A.M., Firth, J.V., Johnson, G.L., Ruddiman, W.F. (Eds.), Proceedings Ocean Drilling Program. Scientific results, pp. 39-59.

Schauer, U., Fahrbach, E., Osterhus, S., Rohardt, G., 2004. Arctic warming through the Fram Strait: Oceanic heat transport from 3 years of measurements. Journal of Geophysical Research 109.

Schlichtholz, P., Houssais, M.-N., 1999. An inverse modeling study in Fram Strait. Part I: dynamics and circulation. Deep-Sea Research II 46, 1083-1135.

Stein, R., 2005. Scientific Cruise Report of the Arctic Expedition ARK-XX/3 of RV "Polarstern" in 2004: Fram Strait, Yermak Plateau and East Greenland Continental Margin.

Tripati, A.K., Eagle, R.A., Morton, A., Dowdeswell, J.A., Atkinson, K.L., Bahé, Y., Dawber, C.F., Khadun, E., Shaw, R.M.H., Shorttle, O., Thanabalasundaram, L., 2008. Evidence for glaciation in the Northern Hemisphere back to 44 Ma from ice-rafted debris in the Greenland Sea. Earth and Planetary Science Letters 265, 112-122.

Vogt, P.R., Crane, K., Sundvor, E., 1994. Deep Pleistocene iceberg plowmarks on the Yermak Plateau: Sidescan and $3.5 \mathrm{kHz}$ evidence for thick calving ice fronts and a possible marine ice sheet in the Arctic Ocean. Geology 22, 403-406.

Wessel, P., Smith, W.H.F., 1991. Free software helps map and display data, EOS Trans. AGU, 72, 441, 1991. Eos Transactions AGU 72, 441.

Winkler, A., Wolf-Welling, T.C.W., Stattegger, K., Thiede, J., 2002. Clay mineral sedimentation in high northern latitude deep-sea basins since the Middle Miocene (ODP Leg 151, NAAG). International Journal of Earth Sciences 91, 133-148.

Wynn, R.B., Masson, D.G., 2008. Sediment waves and bedforms, In: Rebesco, M., Camerlenghi, A. (Eds.), Contourites, pp. 289-300. 


\section{Figure Captions}

Fig. 1: Geographical overview of the Fram Strait and its surroundings. Blue and red arrows mark the present-day predominant surface water flows in this area (Manley et al., 1992). Spacing of bathymetry contour lines is $500 \mathrm{~m}$ down to $2000 \mathrm{~m}$ water depth and $1000 \mathrm{~m}$ at >2000 m water depth. Map was created from the IBCAO dataset (Jakobsson et al., 2008) using GMT software tools (Wessel and Smith, 1991). Geographical names: SvB: Sverdrup Bank; Currents: EGC: East Greenland Current, RAC: Return Atlantic Current, SpB: Spitsbergen Branch, WSC: Western Spitsbergen Current, YB: Yermak Branch. The yellow stars mark the positions of ODP Leg 151 Sites 909 to 912 . Tracklines of the seismic profiles used in this study are shown in white; those mentioned in the text and/or shown in other figures are labeled and shown in yellow. The red part of profile AWI-20040080 is shown in figure $7 \mathrm{a}$, and the red rectangle marks the position of the bathymetry detail in figure $7 \mathrm{~b}$. The dashed pink line at $79^{\circ}$ marks the approximate position of the oceanographic transect in figure 9.

Fig. 2: Compilation of age information used for this study. Timescale after Gradstein et al. (2012), ODP Leg 151 age information from Winkler et al. (2002) and Hull et al. (1996), additional age information on site 909 (i.e., subdivision of Unit I into IA* and IB*) from Knies et al. (2009), and seismostratigraphic information from Geissler and Jokat (2004) and Geissler et al. (2011).

Fig. 3: Upper panel: Interpreted line drawing of seismic profile AWI-20040040 showing the drift bodies "A" and "B" and the field of sediment waves in between. Grey shading indicates the acoustic basement along the profile. Seismostratigraphic unit YP-3 is shown in yellow, YP-2 in orange, and oldest unit YP-1 in green. Lower panel: Unmigrated section of profile AWI-20040040. Trackline of entire profile AWI-20040040 is shown in Fig. 1.

692 Seismostratigraphic units (YP-1 to YP-3) are named after the nomenclature by Geissler et al.

693 (2011), lithostratigraphic unit numbering (IA to IC) according to Site 910 (Hull et al., 1996).

695 Fig. 4: Upper panel: Interpreted line drawing of seismic profile AWI-20040150 showing the drift bodies "A" and "B" and the field of sediment waves in between. Grey shading indicates the acoustic basement along the profile. Seismostratigraphic unit YP-3 is shown in yellow, YP-2 in orange, and oldest unit YP-1 in green. Lower panel: Unmigrated section of profile 
701 Fig. 5: Upper panel: Interpreted line drawing of seismic profile AWI-20040160 showing the 702 drift bodies "A" and "B" and the field of sediment waves in between. Grey shading indicates 703 the acoustic basement along the profile. Seismostratigraphic unit YP-3 is shown in yellow, 704 YP-2 in orange, and oldest unit YP-1 in green. Lower panel: Unmigrated section of profile 705 AWI-20040160. Trackline of entire profile AWI-20040160 is shown in Fig. 1. The orange 706 rectangle in the lower panel marks the position of the detailed view shown in Fig. 6.

708 Fig. 6: Detailed view of the sediment waves observed in profile AWI-20040160. Upper panel: 709 Interpreted line drawing. Lower panel: Unmigrated section.

711 Fig. 7: Upper panel: Interpreted line drawing of seismic profile AWI-97253 showing a 712 channel-levée complex. Grey shading indicates the acoustic basement along the profile.

713 Seismostratigraphic units IA* is shown in yellow, IB* in orange, II in turquoise, IIIA in blue and 714 IIIB in lilac. A huge mass movement deposit is marked by dots. Lower panel: Unmigrated 715 section of profile AWI-97253. Trackline of entire profile AWI-97253 is shown in Fig. 1.

717 Fig. 8: Position of drift body A (in lilac), drift body B (in green), upper sediment wave 718 package (in orange) and lower sediment wave package (hatched). The red ovals mark the 719 positions of the levées identified on profile AWI-97253. ODP Leg 151 Sites 909 to 912 are 720 marked with yellow stars.

722 Fig. 9: a. Detail of the sediment waves in profile AWI-20040080. b. Bathymetry data of parts 723 of the sediment wave field. Crest orientation is marked in pink. Trackline of a. and position of 724 b. are shown in figure 1.

726 Fig. 10: Oceanographic profile at $79^{\circ} \mathrm{N}$ (modified after Fieg et al., 2010; and after Pulm, 727 2010). 


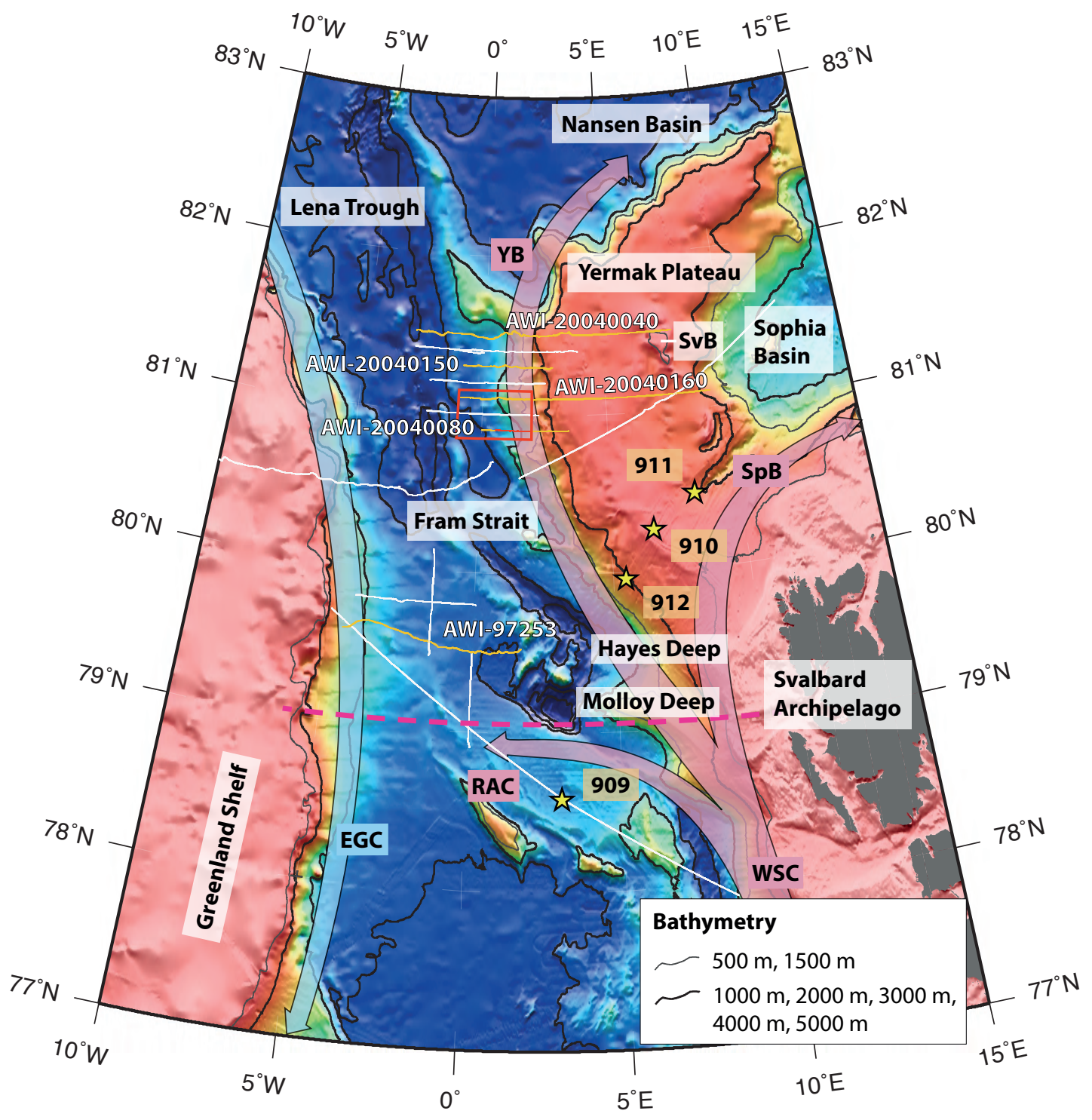




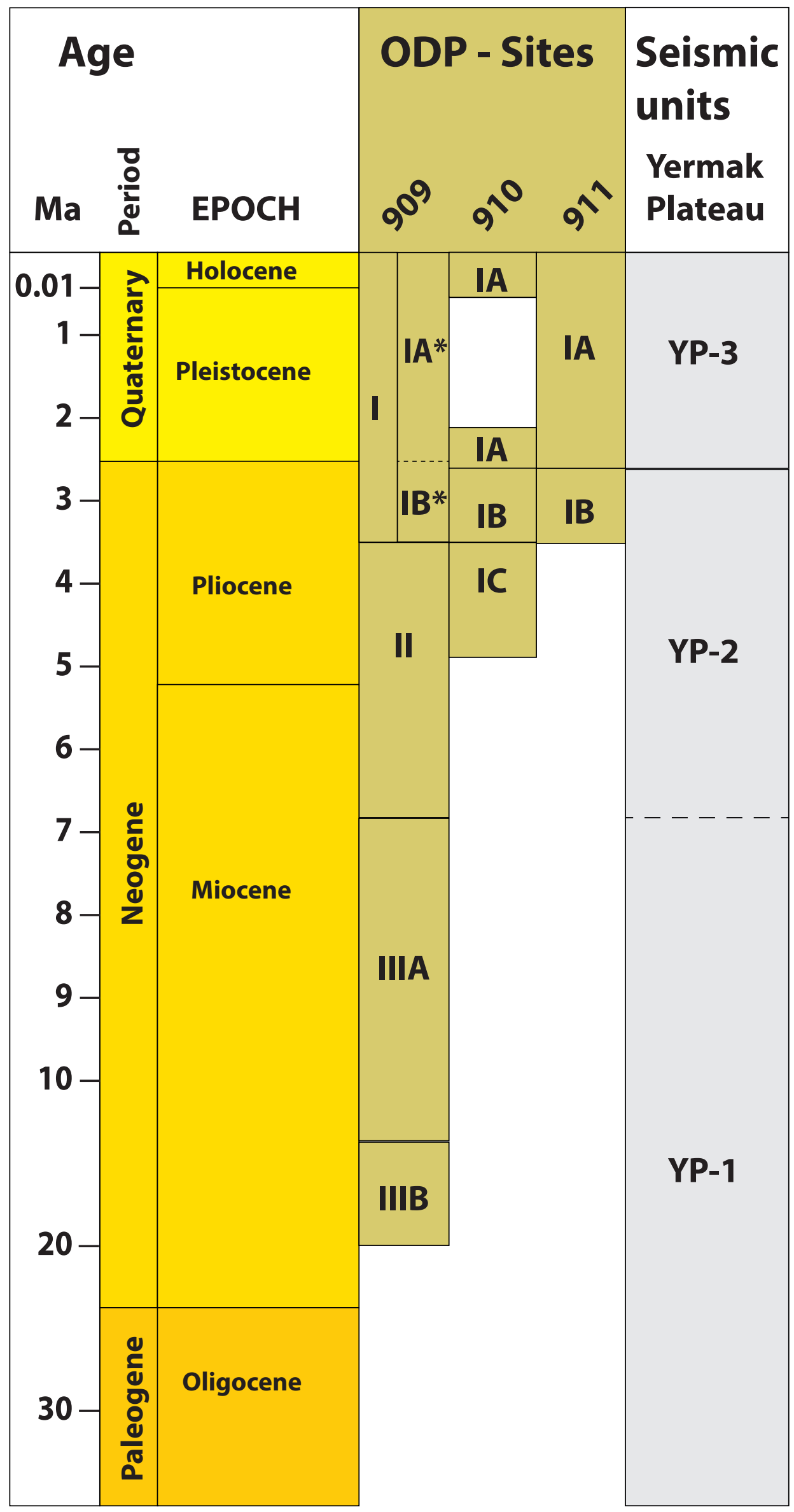



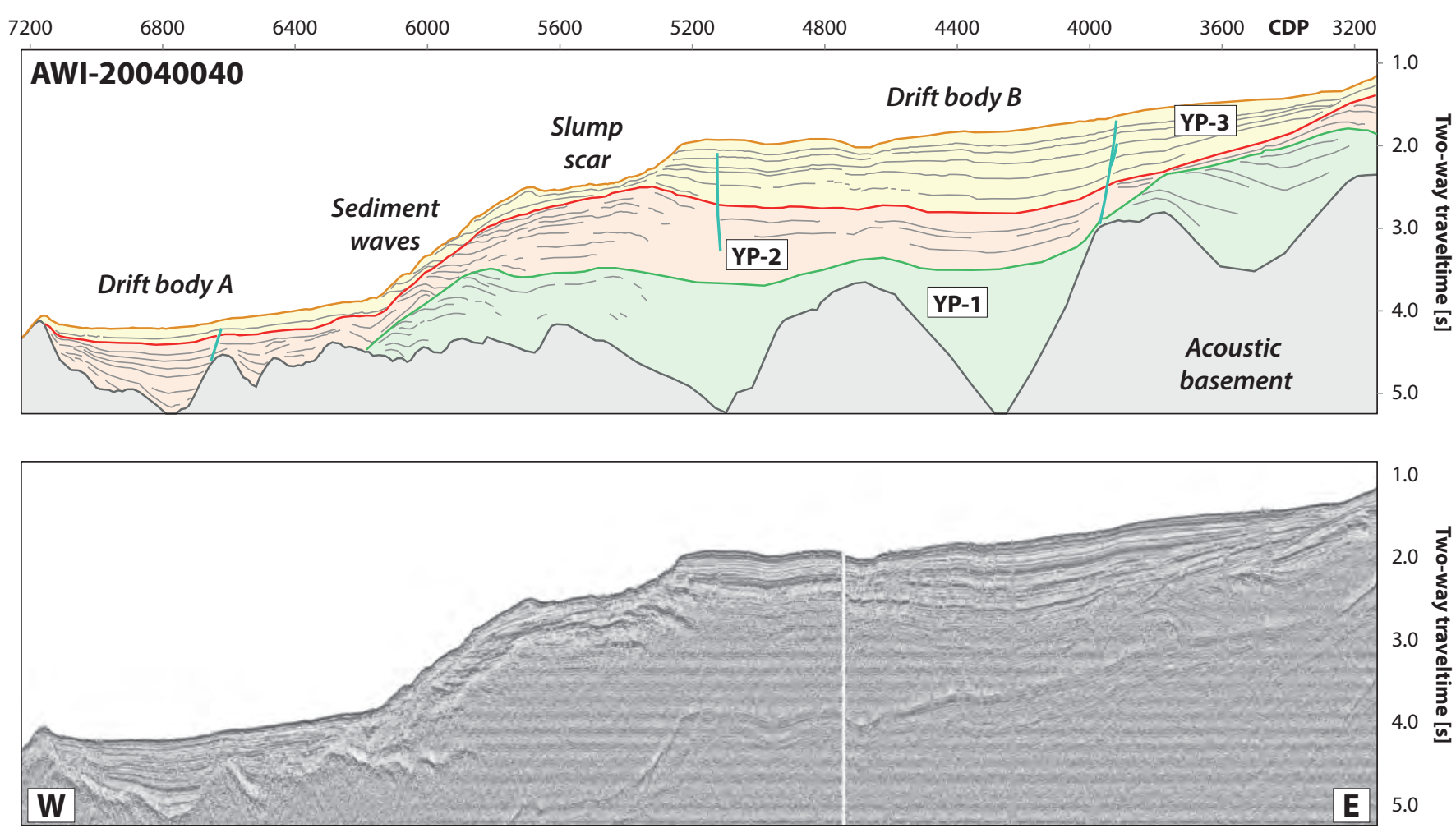

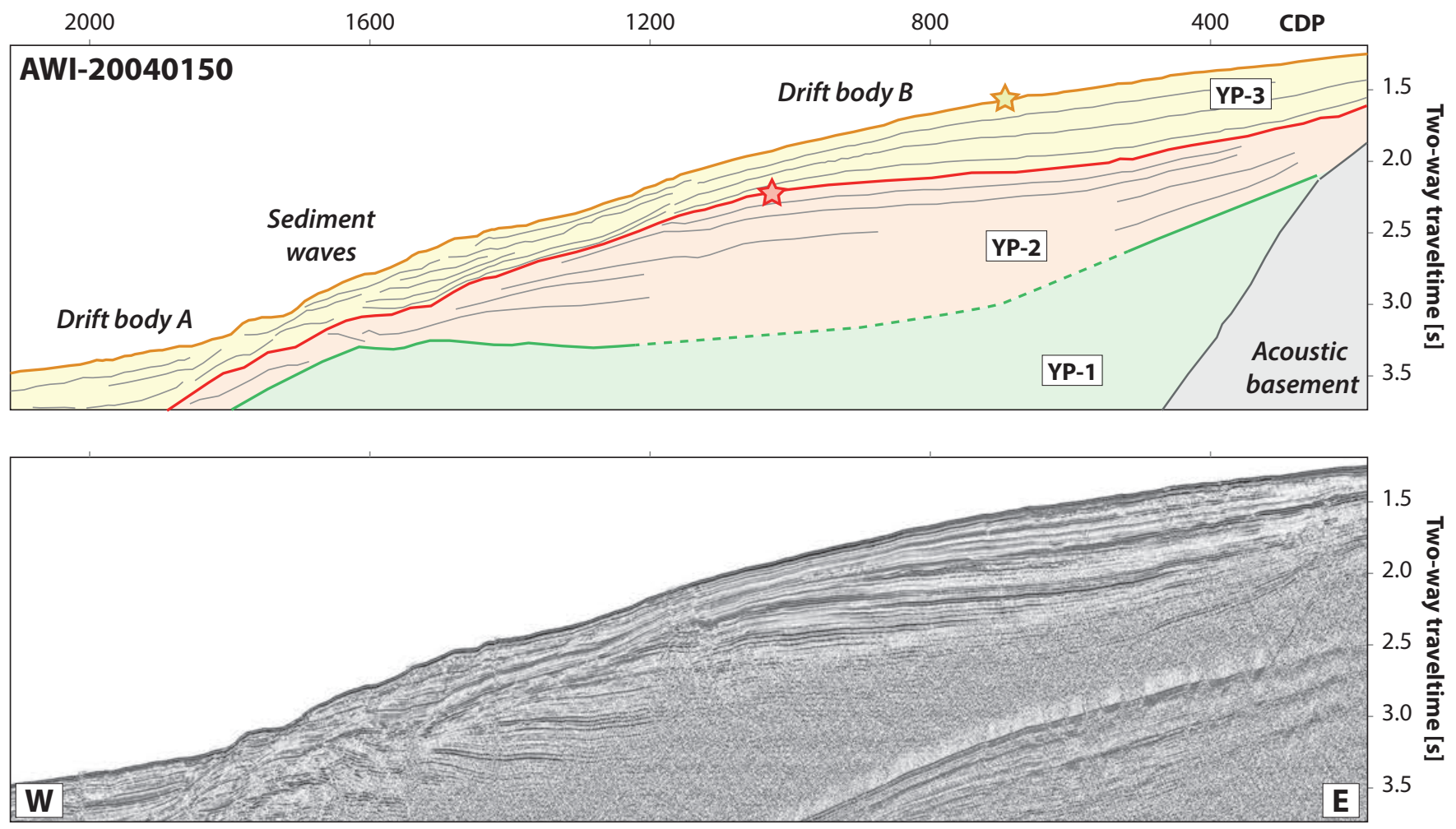

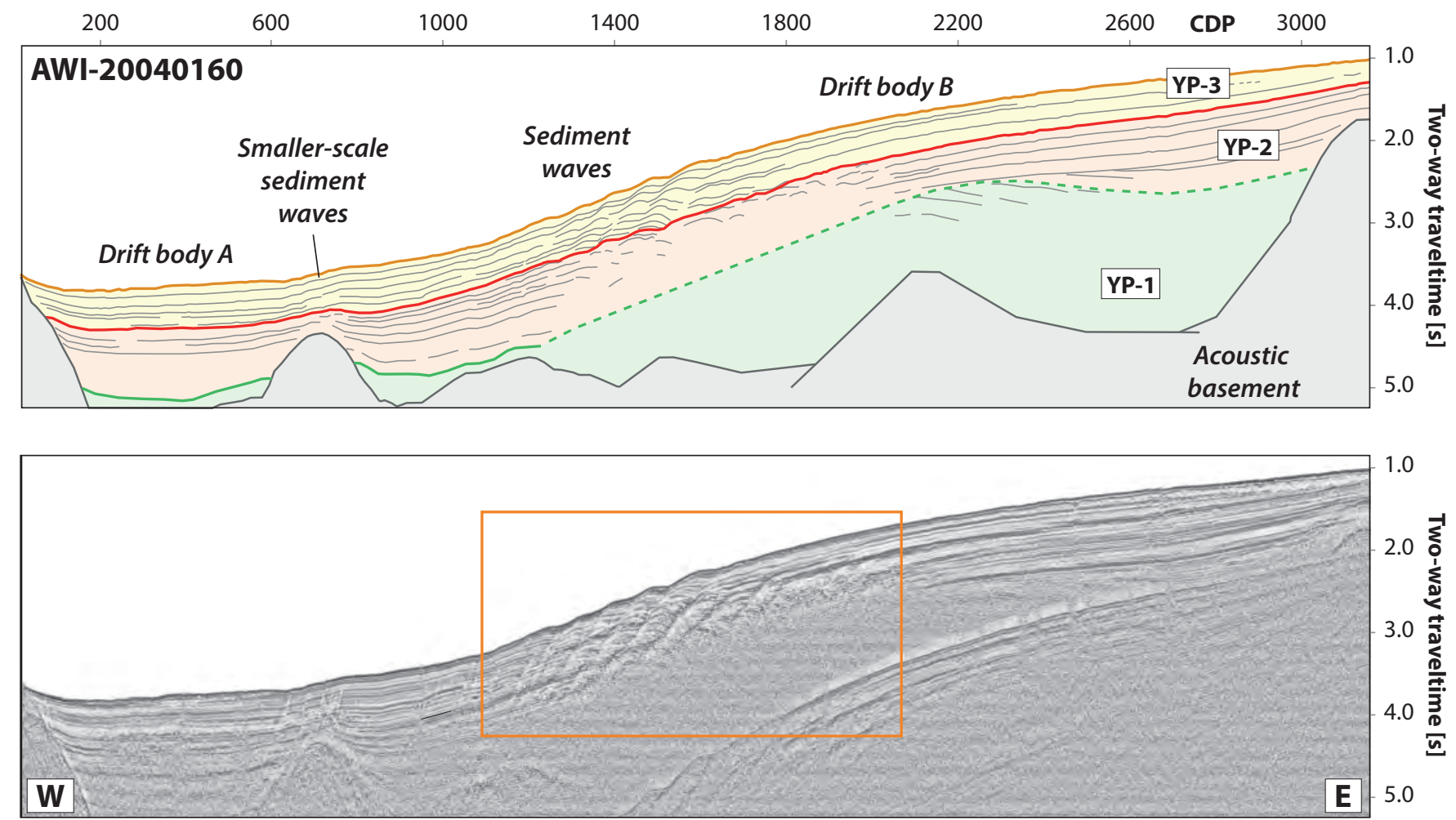

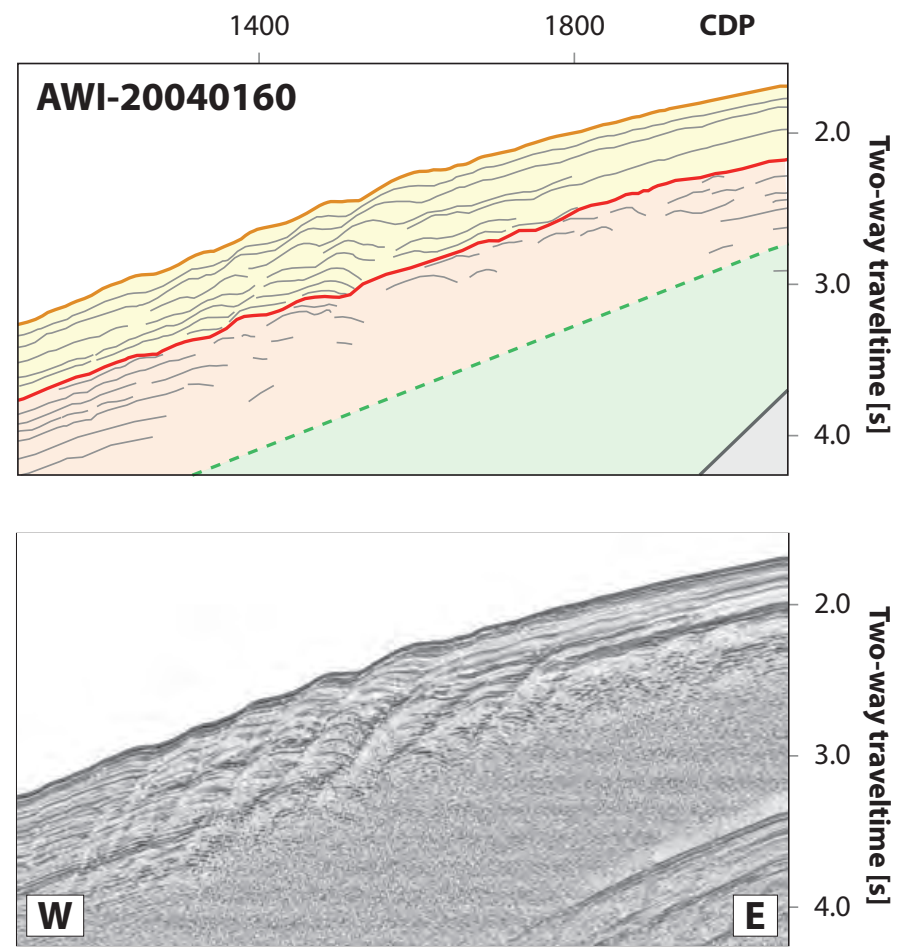

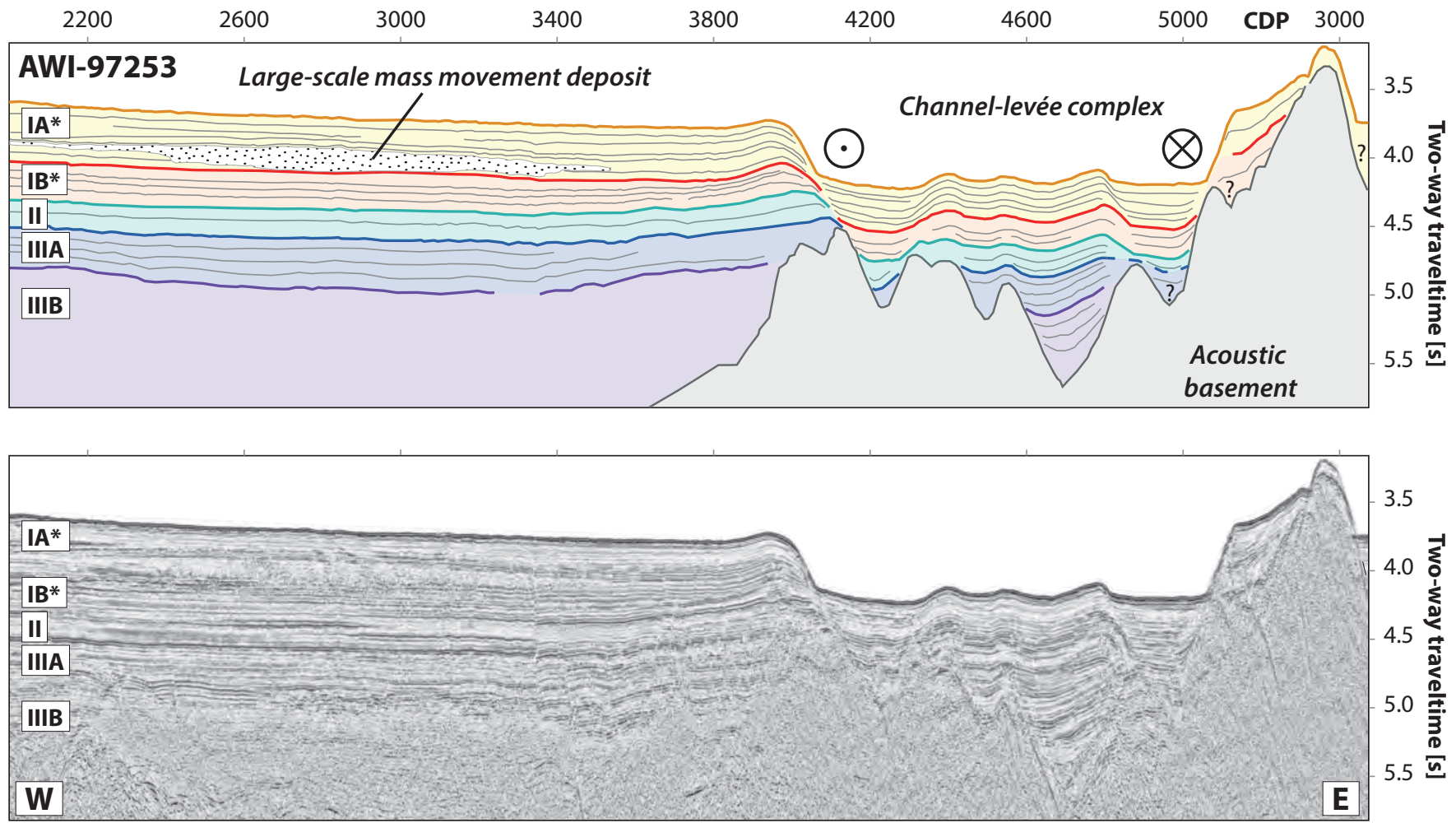


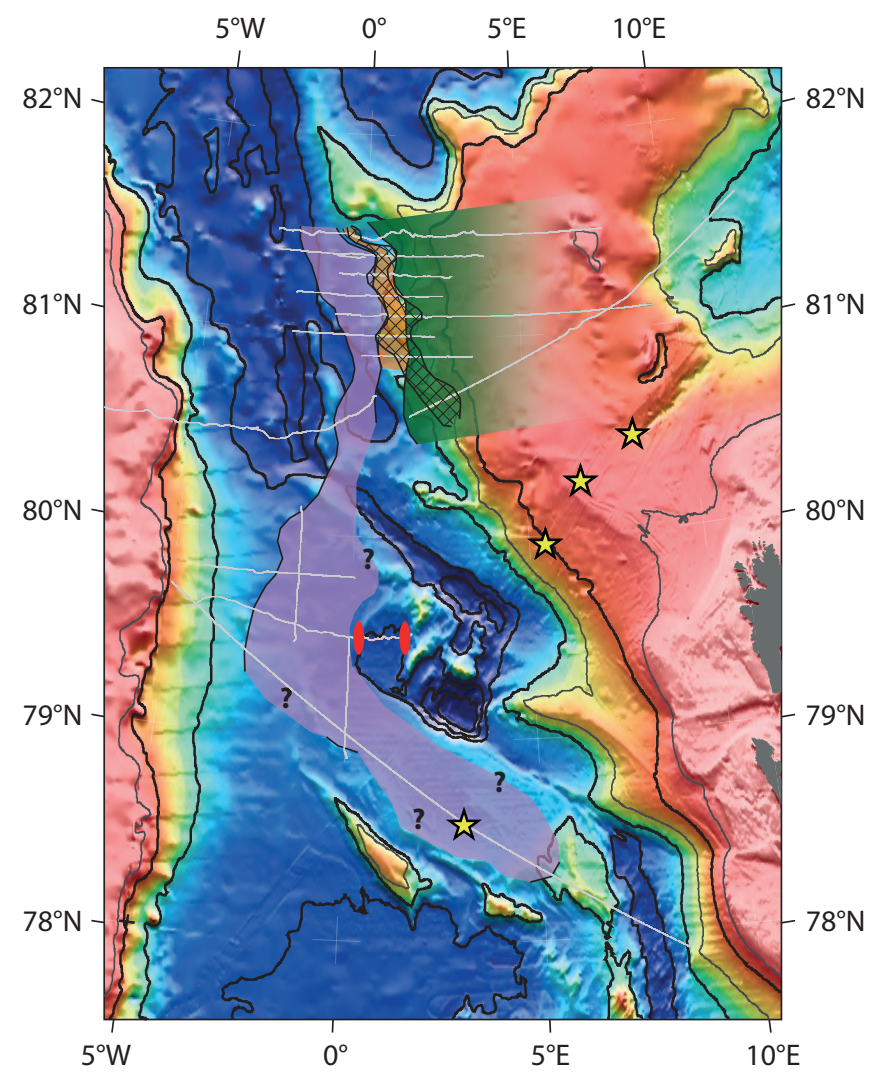



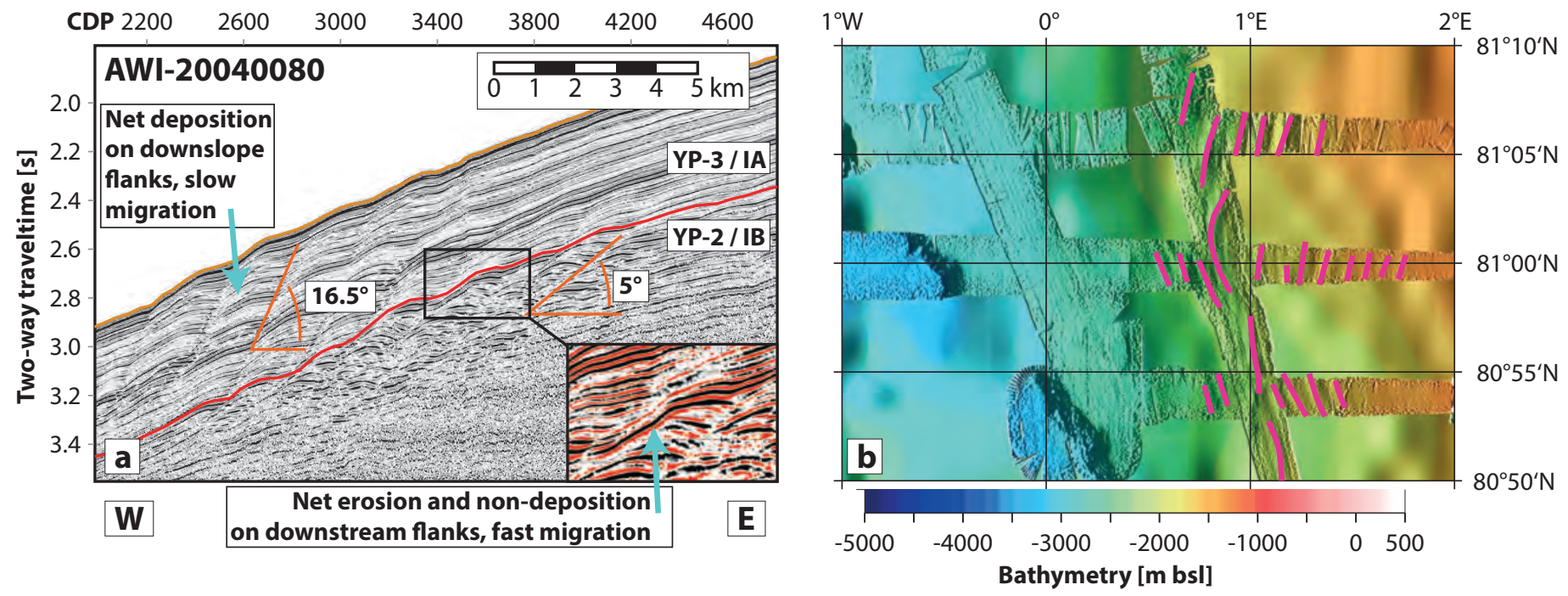
Current velocities through the Fram Strait at $79^{\circ} \mathrm{N}$

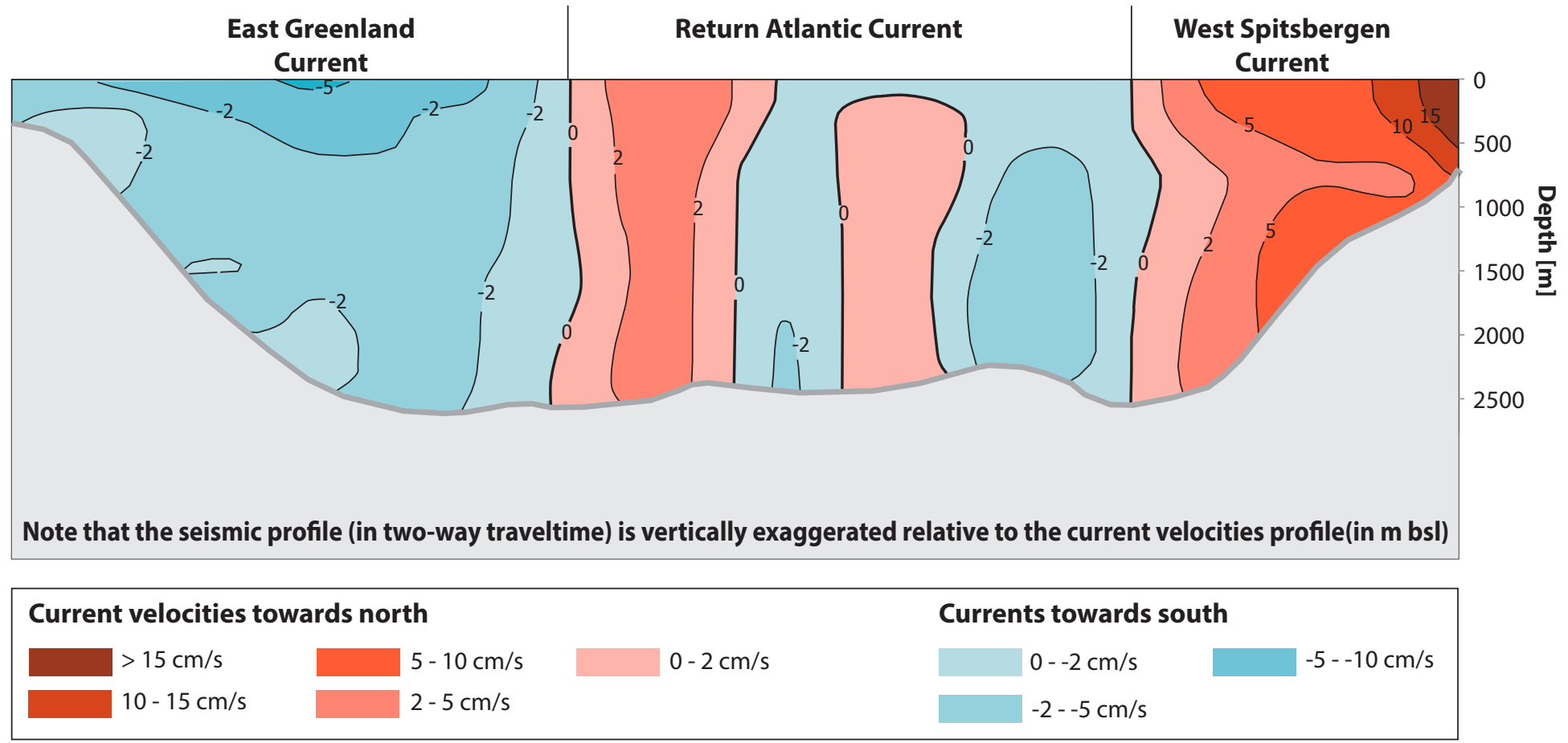

